\title{
PERLINDUNGAN HUKUM BAGI PEKERJA PENYANDANG DISABILITAS PADA PT. SUMBER ALFARIA TRIJAYA
}

\author{
I Wayan Tika Tambunan, I Nyoman Putu Budiartha, Ni Made Puspasutari Ujianti \\ Fakultas IImu Hukum Universitas Warmadewa, Denpasar - Bali, Indonesia \\ tikatambun07@gmail.com, budiartha.fhwjurnal@gmail.com, puspasutari.fhwjurnal@gmail.com
}

\begin{abstract}
Abstrak
Dewasa ini terdapat kasus penyandang disabilitas yang dipekerjakan di suatu perusahaan retail di daerah Bali. Dalam Undang-Undang Ketenagakerjaan diatur ketentuan bagi perusahaan dalam mempekerjakan penyandang disabilitas. Oleh karena itu, perusahaan diwajibkan memberikan suatu aksesibilitas. Penelitian ini dilakukan dengan tujuan mendeskripsikan bagaimana pelaksanaan perlindungan hukum terhadap pekerja disabilitas pada PT. Sumber Alfaria Trijaya berdasarkan Undang-Undang Nomor 13 Tahun 2003 dan faktor apa yang menjadi penghambat dalam penerapan perlindungan hukum terhadap pekerja disabilitas pada PT. Sumber Alfaria Trijaya. Metode penelitian yang digunakan adalah metode penelitian hukum empiris dengan pendekatan fakta dan pendekatan perundang-undangan. Berdasarkan hasil analisis data, pelaksanaan perlindungan hukum yang diberikan PT. Sumber Alfaria Trijaya terhadap pekerja penyandang disabilitasnya belum terpenuhi, yaitu dalam hal pemberian aksesibilitas yang mumpuni. Beberapa faktor penghambat bagi terlaksananya upaya perlindungan hukum bagi para pekerja yang menyandang disabilitas, yaitu faktor penegak hukumnya sendiri dan faktor masyarakat. Maka pemerintah diharapkan lebih mengoptimalkan pengawasan terhadap perusahaan yang belum menerapkan amanat Undang-Undang serta memberikan sosialisasi dan pembinaan terhadap perusahaan dan pekerja akan pentingnya sebuah hak dan kewajiban.
\end{abstract}

Kata Kunci: Perlindungan Hukum; Pekerja Disabilitas

\begin{abstract}
At present, there are cases of persons with disabilities being employed in a retail company in the Bali area. The Manpower Act provides provisions for companies to employ people with disabilities. Therefore, companies are required to provide accessibility. This research was conducted with the aim of describing the implementation of legal protection for workers with disabilities at PT. Sumber Alfaria Trijaya based on Law Number 132003 and the factors that become obstacles in the application of legal protection for workers with disabilities at PT. Source Alfaria Trijaya. The research method used is an empirical legal research method with a factual approach and a statutory approach. Based on the results of data analysis, the implementation of legal protection provided by PT. Sumber Alfaria Trijaya towards workers with disabilities has not been fulfilled, namely in terms of providing qualified accessibility. Several factors inhibiting the implementation of legal protection efforts for workers with disabilities, namely the law enforcement factor itself and the community factor. So the government is expected to further optimize the supervision of companies that have not implemented the mandate of the law and provide socialization and guidance to companies and workers on the importance of rights and obligations.
\end{abstract}

Keywords: Legal Protection; Disability Worker

\section{PENDAHULUAN}

Kualitas ketenagakerjaan merupakan salah satu sektor pendukung dari berkembangnya suatu negara. Sudah seharusnya setiap tenaga kerja yang ada di Indonesia melakukan peningkatan kualitas mereka sebagai tenaga kerja nasional sehingga nantinya mampu membangkitkan serta menjadi dorongan bagi pembangunan guna mengembangkan segala aspek terkait di Indonesia karena dilihat dari pelaksanaan pembangunan nasional itu sendiri. Peran tenaga kerja sangatlah penting baik sebagai pelaku hingga guna mencapai tujuan dari pembangunan itu sendiri.

Menciptakan profesionalitas tidak dapat dilakukan oleh semua pekerja. Semua berdasarkan tingkat kemampuan masing-masing, entah berupa kekurangan yang dibawa semenjak lahir misalnya 
seperti adanya keterbatasan fisik hingga mental termasuk pula intelektualnya (Widinarsih, 2019). Inilah yang dikatakan sebagai penyandang cacat atau bahasa kerennya disabilitas. Untuk itu, guna memaksimalkan kinerja mereka serta kualitasnya, dibutuhkan akses pendukung. Pemberlakukan Undang-Undang Nomor 8 Tahun 2016 Tentang Penyandang Disabilitas di Indonesia di mana hak setiap penyandang disabilitas untuk dapat bekerja atau memperoleh pekerjaan termasuk dengan sarana prasarana yang mumpuni sehingga dapat memungkinakan mereka untuk bekerja dengan optimal karena adanya aksesibilitas yang layak dan cukup. Jadi, pengaksesan layanan publik dalam berbagai kebutuhan di masyarakat menjadi sama rata dengan persamaan kesempatan untuk berpartisipasi di masyarakat. Itu semua semata-mata menghindari adanya diskriminasi.

Tenaga kerja nasional berkewajiban dalam meningkatkan profesionalitasnya tak terkecuali juga pemerintah yang merupakan institusi penting dalam hal meningkatkan kualitas tiap sumber daya manusia (Iroth, 2017; Krismiyati, 2017). Caranya adalah dengan mewujudkan upaya dalam perlindungan bagi para pekerja. Dalam hal ini perhatian yang lebih dapat diberikan bagi para penyandang disabilitas. Untuk mewujudkan itu semua, harus dilakukan secara menyeluruh hingga keluarga mereka termasuk harkat serta martabat mereka.

Berpedoman pada pembukaan Undang-Undang Dasar khususnya Alenia ke-4 mengenai citacita bangsa melakukan perlindungan bagi seluruh bangsa yang juga termasuk di dalamnya para pekerja hingga pengusaha merupakan hal yang wajib dilakukan pemerintah Indonesia atau Negara kita. Menuangkannya dalam suatu aturan perundang-undangan merupakan perwujudan upaya perlindungan yang dilakukan pemerintah bagi terciptanya lingkungan kerja yang adil serta tanpa diskriminasi khususnya bagi kaum penyandang disabilitas. Penjaminan hak untuk menyetarakan setiap orang tanpa memandang berbagai perbedaan yang ada juga merupakan bentuk perlindungan hukum. Upaya ini dapat dilakukan melalui Dinas Ketenagakerjaan dalam menjamin hak serta kewajiban setiap komponen dalam ketenagakerjaan (Istifarroh \& Nugroho, 2019; Rochmawati, Sonhaji, \& Solechan, 2016).

Memperoleh perlindungan merupakan hak dari setiap pekerja atau tenaga kerja termasuk yang menyandang disabilitas (Widjaja, Wijayanti, \& Yulistyaputri, 2020). Bentuk perlindungan yang dapat diberikan berupa kepastian hukum sebelum berangkat pada keadilan itu sendiri, misalnya aturan dasar terkait lama waktu kerja perjanjiannya atau kontrak kerja, jam istirahat, jam pulang, hari libur, lembur, hingga upah yang dibayarkan. Ini semua merupakan perwujudan untuk mengakui hak setiap pekerja yang juga merupakan manusia dan harus diperlakukan secara manusiawi sesuai dengan kemampuan baik mental dan fisik hingga intelektualnya (Husni, 2014).

Mempekerjakan tenaga kerja disabilitas dalam suatu perusahaan bersifat swasta, contohnya PT.Sumber Alfaria Trijaya Cabang Bali yang dikenal dengan supermarket Alfamart. Perusahaan yang merupakan perusahaan retail besar di Indonesia ini sangatlah terkenal keberadaannya di seluruh Indonesia. Perusahaan ini memiliki ketentuan dalam mempekerjakan tenaga kerja yang menyandang disabilitas yaitu dengan kuota sebanyak 4 (empat) orang dan nantinya ditempatkan di cabang atau unit yang telah tersebar di tiap daerah yang terkait. Disinilah penerapan Undang-Undang Nomor 13 Tahun 2003 Tentang Ketenagakerjaan dan Undang-Undang Nomor 8 Tahun 2016 Tentang Penyandang Disabilitas merupakan hal yang sangat dibutuhkan guna menjamin perlindungan serta kepastian hukum bagi para pekerja khususnya penyandang disabilitas ini. Ketentuan Pasal 67 Undang-Undang Ketenagakerjaan merupakan poin penting payung hukum perlindungan bagi tenaga kerja penyandang disabilitas.

Berdasarkan uraian latar belakang di atas, penelitian ini dilakukan dengan tujuan mendeskripsikan bagaimana pelaksanaan perlindungan hukum terhadap pekerja disabilitas pada PT. Sumber Alfaria Trijaya berdasarkan Undang-Undang Nomor 13 Tahun 2003 dan Faktor apa yang menjadi penghambat dalam penerapan perlindungan hukum terhadap pekerja disabilitas pada PT. Sumber Alfaria Trijaya.

\section{METODE PENELITIAN}

Metode penelitian yang digunakan dalam melakukan penelitian ini adalah metode hukum empiris dengan merujuk pada pendekatan perundang-undangan, sosiologis, serta konseptual. Ada beberapa sumber data baik primer atau sekunder yang digunakan seperti Undang-Undang Nomor 1 Tahun 1970 Tentang Keselamatan Kerja, Undang-Undang Nomor 19 Tahun 2011 Tentang Pengesahan Konvensi Mengenai Hak-Hak Penyandang Disabilitas, Undang-Undang Nomor 8 Tahun 2016 Tentang 
Penyandang Disabilitas. Pengumpulan data dilakukan dengan menggunakan metode wawancara kepada pihak terkait PT. Sumber Alfaria Trijaya dan terjun langsung ke lapangan. Data yang telah terkumpul dianalisis dengan menggunakan metode kualitatfi dan disajikan secara deskriptif.

\section{HASIL DAN PEMBAHASAN}

\section{Pelaksanaan Perlindungan Hukum terhadap Pekerja Disabilitas Pada PT. Sumber Alfaria Trijaya berdasarkan Undang-Undang Nomor 13 Tahun 2003}

Philipus dalam buku Harianto menerangkan mengenai makna perlindungan hukum itu sendiri yang dikatakan berkaitan dengan kekuasaan, baik kekuasaan pemerintah yang seringkali bertentangan dengan kebutuhan masyarakat dalam hubungannya hingga kekuasaan ekonomi terkait perlindungan para pelaku ekonomi dari yang lemah dengan si kuat atau pekerja dengan pengusaha (Harianto, 2016).

Dalam melaksanakan kewajibannya dengan optimal, pekerja penyandang disabilitas dapat berpedoman pada dasar hukum yang ada sehingga hak-haknya juga dapat terpenuhi. Salah satu produk hukum yang dapat digunakan adalah Undang-Undang Ketenagakerjaan Nomor 13 Tahun 2003. Disebutkan dalam ketentuan Pasal 67 ayat (1) bahwa kewajiban bagi tiap perusahaan atau pengusaha yang menjadikan penyandang disabilitas sebagai pekerjanya adalah untuk memberikan berbagai upaya perlindungan sebagaimana sesuai dengan tingkat kecacatan dari pekerjanya tersebut, contohnya penyediaan sarana prasarana kerja aksesibilitas hingga perlengkapan perlindungan diri yang sesuai dan mumpuni. Aksesibilitas ini juga dapat ditemukan pengaturannya dalam ketentuan pada Pasal 18 Undang-Undang Nomor 8 Tahun 2016. Pekerja sendiri merupakan para pelaku kerja atau penerima upah atau imbalan sebagai hasil dari kerja kerasnya imbalan yang diterima tidak hanya dalam bentuk uang tapi juga dalam bentuk lain (Maimun, 2007).

Mewujudkan upaya perlindungan hukum oleh PT. Sumber Alfaria Trijaya dapat dilakukan melalui penerapan beberapa peraturan perundang-undangan terkait seperti Undang-Undang Nomor 8 Tahun 2016 dalam Pasal 53 Undang-Undang ini mengenai kewajiban mempekerjakan setidaknya 1\% jatah atau kuota bagi para penyandang disabilitas khusus perusahaan swasta. Sementara itu PT. Sumber Alfaria Trijaya mengajak pekerja disabilitas untuk dipekerjakan sebanyak 4 (empat) orang dari yang memiliki kondisi disabilitas secara fisik (tuna daksa) biasanya kekurangannya disebabkan karena mengalami kecelakaan sehingga kondisi fisik kurang lengkap atau sempurna. Pekerja ini ditempatkan pada cabang atau unit outlet Alfamart dengan penempatan yang telah terbagi-bagi sesuai kebutuhan tenaga kerja maka untuk itu penempatannya acak.

Salah satu pekerja disabilitas yang menjadi narasumber dalam penelitian ini yaitu Bapak Muhammad Tarmizi. Beliau merupakan pekerja penyandang disabilitas yang dipekerjakan oleh PT. Sumber Alfaria Trijaya. Berdasarkan hasil wawancara, beliau mengatakan selama ia bekerja pada Alfamart tidak pernah adanya hambatan dengan upah serta jam kerja yang selalu tepat dan tidak pernah diberikan tambahan waktu jam kerja. Alfamart juga memberikan pelatihan kerja saat beliau dalam proses rekrutmen pada PT. Sumber Alfaria Trijaya namun beliau mengeluhkan terhadap penempatan ia bekerja karena beliau sempat mengajukan untuk pindah penempatan outlet dengan tempat tinggalnya. Namun perusahaan mengatakan jika penempatan itu sudah memiliki sistem dari kantor pusat, sehingga ia mau tidak mau terpaksa menjalani akses dalam pekerjaan dengan perjalanan yang jauh dan dengan kondisinya saat ini beliau saat ini ditempatkan pada outlet Alfamart yang beralamatkan Jalan Nangka Utara Tonja Denpasar Utara sedangkan tempat tinggalnya berada di Jalan Cokroaminoto Gg. Belimbing No. 4 Ubung Denpasar Utara.

Dari pernyataan bapak Tarmizi tersebut ditemukan bahwa ketentuan Pasal 48 Undang-Undang Ketenagakerjaan tidak terpenuhinya oleh pihak PT. Sumber Alfaria yang mana penempatan tenaga kerja kurang fleksibel atau tidak mengutamakan kepentingan pekerja dengan aksesibilitas sesuai tingkat derajat disabilitasnya seperti yang tercantum dalam Undang-Undang tersebut sebagaimana Pasal 67 yang mengatur seperti itu. Dalam hal ini Bapak Muhammad Tarmizi yang bertempat tinggal di Jalan Cokroaminoto Gg. Belimbing No. 4 Ubung Denpasar Utara menuju tempat kerjanya di Jalan Nangka Utara Tonja Denpasar Utara. Sehingga kita dapat perhatikan bahwa aksesibilitasnya atau kemudahannya dalam perjalanan kerja Bapak Muhammad Tarmizi belum terpenuhi dengan kondisi tuna daksa, sehingga selama ini beliau dalam menjalankan kewajibannya sebagai pekerja ia diantar jemput oleh kerabatnya untuk menuju outlet dimana ia bekerja.

Penyediaan aksesibilitas yang layak atau mumpuni untuk setiap pekerja merupakan tugas kewajiban tiap perusahaan atau pengusaha dalam memfasilitasi pekerjanya khususnya penyandang 
disabilitas karena dampak penyediaan aksesibilitas yang baik sangat besar dalam pengaruhnya dengan tingkat kinerja para pekerja yang ada. Maka dari itu, PT. Sumber Alfaria Trijaya saat ini belum dapat menerapkan suatu aksesibilitas dalam perlindungan hukum bagi pekerja Penyandang Disabilitas di perusahaannya.

\section{Faktor-faktor Penghambat Penerapan Perlindungan Hukum terhadap Pekerja Disabilitas pada PT. Sumber Alfaria Trijaya}

Setiap pengaplikasian suatu produk hukum tidak semua berjalan sesuai harapan. Pasti ada saja pelanggaran terhadap ketentuan-ketentuan tertentu yang menjadikannya hambatan bagi penegakkan hukum yang ada saat ini, salah satunya bentuk perlindungan hukum yang masih menjadi hutang pelaksanaannya oleh PT. Sumber Alfaria Trijaya terhadap pekerja disabilitasnya yang berdasarkan pasal 67 Undang-Undang Disabilitas Nomor 13 Tahun 2003 masih banyak terdapat kekurangan. Pelaksanaannya belum sesuai ketentuan di atas seperti hak aksesibilitas mumpuni bagi para pekerja yang menyandang disabilitas.

Pasal 67 Undang-Undang Nomor 13 Tahun 2003 mengatur mengenai ketentuan yang harus dipenuhi perusahaan dalam menyediakan aksesibilitas bagi para pekerja yang menyandang disabilitas sesuai dengan tingkat kecacatan pekerja. Begitu pula pada PT. Sumber Alfaria Trijaya masih belum memenuhi seluruh ketentuan yang ada bagi para pekerjanya. Para pekerja penyandang disabilitas yang ditempatkan di setiap cabang atau unit outlet. Seringkali tak manusiawi karena kadang jarak penempatan yang jauh dari rumah atau tempat domisilinya. Terbebani dengan itu semua, belum lagi kemampuan yang kurang, serta kondisi yang tak mumpuni, menjadi kendalanya untuk bekerja layaknya orang normal.

Teori efektivitas hukum yang merupakan pendapat dari Soekanto, ada 5 penekanan atau faktor yang dapat mempengaruhi keefektivitasan suatu hukum yang ada di antaranya adalah faktor internal yang terdiri dari hukum itu sendiri dan beberapa faktor eksternal yaitu masyarakat penegak hukumnya kebudayaan serta penegakan hukum itu sendiri (Soekanto, 2008).

Dari beberapa faktor tersebut di atas, jika dikaitkan dengan penelitian mengenai perlindungan untuk para pekerja disabilitas di PT. Sumber Alfaria Trijaya ini, dapat ditemukan beberapa faktor terkait, yaitu ditinjau dari faktor para penegak hukumnya dan faktor masyarakat itu sendiri.

1. Faktor penegak hukum yaitu pihak-pihak yang membentuk maupun menerapkan hukum

Penegak hukum disini dapat kita lakukan adalah pihak pemerintah daerah yang melakukan pengawasan terkait persoalan ketenagakerjaan, yaitu Dinas Ketenagakerjaan dan Sumber Daya Mineral Provinsi Bali. Mereka memiliki tugas dalam upaya penegakkan serta pengawasan hukum terkait penerapan aturan hukum terkait ketenagakerjaan. Adapun salah satu tugas Dinas Tenaga Kerja dan ESDM Provinsi Bali, yaitu melakukan pengadaan sosialisasi berintegritas terkait aturan-aturan kerja, seperti keselamatan kerja, kesehatan para pekerja yang dapat dilakukan dengan para pekerja yang menyandang disabilitas untuk dapat memperoleh perlindungan hukum di dunia kerja dengan tanpa adanya diskriminasi di lingkungan kerja karena untuk saat ini masih ada aksesibilitas yang belum terpenuhi untuk pekerja penyandang disabilitas dalam PT. Sumber Alfaria Trijaya di daerah Bali ini. Oleh karena itu, dapat dilihat bahwa Dinas Tenaga Kerja dan ESDM Provinsi Bali masih dianggap kurang tegas dalam menindaklanjuti permasalahan ini.

Ibu Manila Ayupijaya selaku Pejabat Fungsional Pengantar Kerja mengatakan pengawasan yang dilakukan oleh Dinas Tenaga Kerja dan ESDM Provinsi Bali dalam melakukan pengawasan belum dapat menerapkan sanksi yang cukup tegas bagi perusahaan-perusahaan yang kurang memenuhi ketentuan aturan perundang-undangan yang ada sehingga menyebabkan kurang optimalnya penyidikan terhadap para pelanggar aturan tersebut dengan mana jumlah personil pengawas dengan perusahan yang diawasi berbanding terbalik jumlahnya. Inilah yang dianggap masih kurang efisien dan optimal dalam melakukan tugas mereka. Menurut beliau, pengawasan masih kurang optimal dilakukan oleh pihak Dinas Tenaga Kerja dan ESDM sehingga menimbulkan hambatan-hambatan dalam upaya menegakkan hukum yang mereka lakukan. Begitu juga berdampak terhadap upaya perlindungan hukum bagi tenaga kerja khususnya tenaga kerja Penyandang Disabilitas, meskipun effort atau usaha maksimal dengan diadakannya sosialisasi guna mengajak perusahaan-perusahaan yang ada lebih optimal melaksanakan ketentuan peraturan yang ada sehingga memberikan pemahaman pentingnya upaya perlindungan hukum bagi pekerja yang menyandang disabilitas khususnya, namun masih saja terdapat kekurangan dalam praktek riilnya di lapangan. 


\section{Faktor Masyarakat}

Salah satu alasan pembentukkan suatu hukum itu sendiri adalah untuk kepentingan masyarakat karena itulah hukum disebut Cicero lahir dan bersumber dari masyarakat. Hukum berperan penting dalam menciptakan keharmonisan ketentraman kedamaian serta keadilan bagi masyarakat. Namun perlu digaris bawahi kembali lagi kepada kesadaran tiap masyarakat itu sendiri yang mana setiap masyarakat memiliki pemahaman berbeda dan kesadaran berbeda terkait hukum itu, sehingga diperlukan pembinaan lebih ekstra terkait produk hukum yang ada kepada masyarakat. Disinilah dapat kita ketahui bahwa kesadaran hukum masyarakat sangat berperan dalam upaya penegakan hukum yang ada sehingga nantinya beberapa tujuan hukum semestinya dapat tercapai di lingkungan masyarakat.

Berdasarkan wawancara bersama Bapak Diki Artanaya selaku Manajer pada PT. Sumber Alfaria Trijaya, hambatan yang terjadi dikarenakan mekanisme penempatan pekerja yang masih kurang efisien sesuai dengan aturan dari kantor pusat PT. Sumber Alfaria Trijaya dimana setiap pekerja baru ditempatkan sesuai dengan outlet yang membutuhkan karyawan sehingga terjadilah penempatan di tempat-tempat acak yang mana bisa sangat jauh dari tempat tinggal pekerja.

Untuk upaya penyelesaian serta dalam mengatasi setiap hambatan tersebut di atas, beberapa upaya yang dapat dilakukan adalah dengan adanya kesinergian antara dua vektor tersebut di atas untuk mengoptimalkan dalam memperbaiki kesalahan dan kekurangan mereka sehingga dapat membantu dalam upaya perlindungan hukum bagi pekerja yang menyandang disabilitas di PT. Sumber Alfaria Trijaya daerah Bali khususnya.

\section{SIMPULAN DAN SARAN}

\section{Simpulan}

Berdasarkan hasil dan pembahasan yang telah dipaparkan di atas, ada beberapa simpulan yang dapat dibuat, yaitu: pertama, pelaksanaan perlindungan hukum yang diberikan PT. Sumber Alfaria Trijaya terhadap pekerja penyandang disabilitasnya belum terpenuhi, yaitu dalam hal pemberian aksesibilitas yang mumpuni. PT. Sumber Alfaria Trijaya khususnya di daerah Bali masih belum cukup optimal dalam pelaksanaannya memenuhi upaya perlindungan bagi pekerja yang menyandang disabilitas seperti halnya dalam memenuhi standar aksesibilitas sebagaimana Undang-Undang Ketenagakerjaan Nomor 13 Tahun 2003 menghimbaunya dalam ketentuan pasal 67. Kedua, beberapa faktor penghambat bagi terlaksananya upaya perlindungan hukum bagi para pekerja yang menyandang disabilitas, yaitu faktor penegak hukumnya sendiri dan faktor masyarakat.

\section{Saran}

Ada beberapa saran yang perlu disampaikan berdasarkan hasil dan pembahasan penelitian ini, yaitu: pertama, terkait pengoptimalan penerapan suatu aturan ketentuan hukum untuk perlindungan pekerja disabilitas bagi pihak perusahaan PT. Sumber Alfaria Trijaya, pemerintah dan instansi terkait khususnya Dinas Tenaga Kerja dan ESDM Provinsi Bali sebaiknya melakukan pengawasan yang lebih ketat dan tegas dalam penindakannya. Kedua, bagi perusahaan dan pemerintah yang belum sepenuhnya mengaplikasikan ketentuan dalam Undang-Undang Nomor 8 Tahun 2016 tentang Penyandang Disabilitas dimana tertera kewajiban dalam mempekerjakan setidaknya $1 \%$ para pekerja yang menyandang disabilitas di wilayah perusahaan dan $2 \%$ untuk wilayah pemerintahan, untuk tetap memperhatikan hak dari para pekerjanya yang menyandang disabilitas.

\section{DAFTAR PUSTAKA}

Harianto, A. (2016). Hukum Ketenagakerjaan Makna Kesusilaan dalam Perjanjian Kerja. Yogyakarta: LaksBang PRESSindo.

Husni, L. (2014). Pengantar Hukum Ketenagakerjaan Indonesia. Jakarta: Rajawali Pers.

Iroth, D. A. (2017). Aspek Hukum Pengembangan Sumber Daya Manusia (SDM) Menurut UndangUndang No. 13 Tahun 2003 Tentang Ketenagakerjaan. Lex, 4(2), 12-21.

Istifarroh, \& Nugroho, W. C. (2019). Perlindungan Hak Disabilitas Mendapatkan Pekerjaan di Perusahaan Swasta dan Perusahaan Miliki Negara. Mimbar Keadilan, 12(1), 21-34.

Krismiyati. (2017). Pengembangan Sumber Daya Manusia dalam Meningkatkan Kualitas Pendidikan di SD Negeri Inpres Angkasa Biak. Jurnal Office, 3(1), 43.

Maimun. (2007). Hukum Ketenagakerjaan Suatu Pengantar. Jakarta: PT. Kresna Prima Persada. 
Rochmawati, A. E., Sonhaji, \& Solechan. (2016). Perlindungan Hukum bagi Tenaga Kerja Penyandang Disabilitas dalam Pemenuhan Hak-Hak Pekerja berdasarkan Undang-Undang Nomor 13 Tahun 2003 Tentang Ketenagakerjaan di Kabupaten Semarang. Diponegoro Law Review, 5(2), 1-13.

Soekanto, S. (2008). Faktor-Faktor yang Mempengaruhi Penegakan Hukum. Jakarta: PT. Raja Grafindo Persada.

Widinarsih, D. (2019). Penyandang Disabilitas di Indonesia: Perkembangan Istilah dan Definisi. Jurnal Ilmu Kesejahteraan Sosial, 20(2), 127-142.

Widjaja, A. H., Wijayanti, W., \& Yulistyaputri, R. (2020). Perlindungan Hak Penyandang Disabilitas dalam Memperoleh Pekerjaan dan Penghidupan yang Layak bagi Kemanusiaan. Jurnal Konstitusi, 17(1), 197-223. 